\title{
Path Analysis on the Determinants of Visual Inspection Acetic Acid Utilization on Early Detection of Cervical Cancer: Application of Health Belief Model Theory
}

\author{
Elfania Arumma Sunarta1), Endang Sutisna Sulaeman²), Uki Retno Budihastuti3) \\ 1)Masters Program in Public Health, Universitas Sebelas Maret \\ 2)Departement of Public Health, Faculty of Medicine, Universitas Sebelas Maret \\ 3)Departement of Obstetrics and Gynecology, Dr. Moewardi Hospital, Surakarta
}

\begin{abstract}
Background: Cervical cancer was a serious health problem for women and VIA screening provided many benefits to women, which was to detect early cervical cancer. This study aimed to determine the determinants that influence the use of VIA with the theory of Health Belief Model on women of reproductive age.

Subjects and Method: This was an analytic observational study with a case-control approach, conducted in the working area of Wongsorejo Public Health Center, Banyuwangi, East Java from March to April 2019. The sampling technique used was Fixed Disease Sampling, with a ratio of 1:3. Samples from 150 women reproductive age who had not used VIA screening and 50 women who had conducted VIA screening. Independent variables were perceived susceptibility, perceived severity, perceived benefits, cues to action, self-efficacy, knowledge, attitudes, access to services and husband's support. The dependent variable was the use of VIA. Data were collected by questionnaire and analyzed by path analysis.

Results: The use of VIA screening was directly affected and has a positive effect on perceived vulnerability $(b=1.45 ;$ CI $95 \%=0.50$ to $2.40 ; p=0.003)$, perceived severity $(b=0.86 ; C I 95 \%=-0.16$ to 1.88; $\mathrm{p}=0.099)$, perceived benefit $(\mathrm{b}=1.61$; CI $95 \%=0.52$ to $2.68 ; \mathrm{p}=0.003)$, cues to action $(b=$ 1.21 ; CI $95 \%=0.05$ to $2.37 ; p=0.040)$, high efficacy $(b=1.26$; CI $95 \%=0.27$ to $2.26 ; p=0.012)$, attitude $(b=1.83$; CI $95 \%=0.81$ up to 2.85$)$ and husband support $(b=1.59$; CI $95 \%=0.63$ to 2.55$)$. The use of VIA screening was indirectly influenced by access to health services and knowledge.

Conclusion:The use of VIA screening was directly influenced by perceived vulnerability, perceived severity, perceived benefits, perceived barriers, cues to act, self-efficacy, attitude and husband support. And it was indirectly influenced by access to services and knowledge.
\end{abstract}

Keywords: VIA, Cervical Cancer, Health Belief Model, Path Analysis

Correspondence:

Elfania Arumma Sunarta. Masters Program in Public Health, Universitas Sebelas Maret, Jl. Ir. Sutami No. 36 A, Surakarta, Indonesia. Email: elfaniaas@gmail.com. Mobile: +6282272434301

\section{BACKGROUND}

Cancer was the leading cause of death worldwide. Cervical cancer caused $7.5 \%$ of female deaths, $85 \%$ occurred in developing countries (WHO, 2016). Cervical cancer was a serious threat to women's health and life. Globally, one woman died of cervical cancer every two minutes. This situation can be prevented, especially because cervical cancer was largely preventable (WHO, 2018).
The target of VIA examination in Indonesia was $37,415,483$ people $(29.07 \%)$ with the number of examinations up to 2017 by 3,040,116 people (8.12\%) (Ministry of Health Republic of Indonesia, 2017). The number of targets for VIA examination in East Java Province was 6,278,356 people (31.72\%). VIA examination was performed on 88,135 women (1.4\%) with a positive result of cervical cancer by 7.013 (7.96\%) (Ministry of Health, 2017). 
In 2016, in Banyuwangi, the target of VIA examination in women aged 30 to 50 years old was 257,499 women of reproductive age (32.03\%), and 4,305 women (1.67\%) were tested with 299 positive results of cervical cancer (6.95\%) (City Health Office Banyuwangi, 2016). In 2018 the participation of women in the work area of Wongsorejo Health Center in detecting early cervical cancer was still low. The number of VIA examinations was 367 people (5.4\%) with a positive result of 3 people (o.8\%). This number was very far from the target of health center which did not reach $10 \%$, which was 673 women out of a total of 6,734 women.

Women's attitude and interest in screening was a cause of delay in detecting cervical cancer early. This was because many women considered that cervical cancer screening was still taboo. Cervical cancer was also called the silent killer. Screening can detect early cervical cancer at an early stage and high potential for recovery if immediate treatment was carried out (WHO, 2013).

This study was conducted to determine the determinants that influence the use of VIA by applying the theory of Health Belief Model.

\section{SUBJECTS AND METHOD \\ 1. Study Design \\ This was an analytic observational study with case-control approach, conducted in the working area of Wongsorejo Health Center, Banyuwangi, from March to April 2019.}

\section{Population and Sample}

The target population in this study were women of reproductive age in the work area of Wongsorejo Health Center, Banyuwangi, East Java. The sampling technique used was Fixed Disease Sampling, with a ratio of 1:3. Samples from 150 women who had not used VIA screening and 50 women who had done VIA screening.

\section{Study Variables}

The dependent variable was the use of VIA. The independent variables were perceived susceptibility, perceived severity, perceived benefit, cues to action, self-efficacy, knowledge, attitudes, access to health services, and husband support.

\section{Definition of Operational Variables}

The use of VIA was an attempt made to detect early the existence of cervical cancer or the existence of clinical abnormalities that were not yet clear by using certain tests or examinations that can be used quickly to determine the existence of a disease that was the object of screening.

Perceived susceptibility was a subjective perception of someone about the risk of contracting the disease, as well as the possibility that assumed at the risk of someone suffering from certain diseases or adverse health effects.

Perceived severity were perceptions of the severity of the disease or leaving it untreated, according to circumstances or actions that might occur.

Perceived benefit was someone who felt the benefits obtained when paying for health facilities and services compared to the risk of the disease.

Cues to action was the stimulus to act which was the stimulus needed to trigger the decision making process so that health behavior occurred.

Self efficacy was the belief in someone's own ability to do something. Self-efficacy can be seen as a person's beliefs about the extent to which she was able to control her motivation, behavior, and social environment, which was needed to produce a behavior.

Knowledge was a result of "know" and this happened after people have sensed a certain object. 
Journal of Health Promotion and Behavior (2019), 4(1): 32-42

https://doi.org/10.26911/thejhpb.2019.04.01.04

Attitude was readiness or willingness to act, and not an implementation of certain motives.

Service access was at any time needed, for healthy behavior, the community needed supporting facilities and infrastructure.

Husband support was information from the husband that she was loved and cared for, has self-esteem, valued, and was part of the communication network and shared obligations.

\section{Study Instrument}

The study instrument used for data collection was a questionnaire. The instruments were tested for content validity and face validity and reliability testing.

\section{Data Analysis}

\section{Table 1.Distribution of Study Subjects of VIA Utilization}

\begin{tabular}{|c|c|c|c|}
\hline \multicolumn{2}{|c|}{ Characteristics } & $\mathbf{n}$ & $\%$ \\
\hline Perceived Susceptibility & Low & 136 & 68.0 \\
\hline & High & 64 & 32.0 \\
\hline \multirow{2}{*}{ Perceived Severity } & Low & 111 & 55.5 \\
\hline & High & 89 & 44.5 \\
\hline \multirow{2}{*}{ Perceived Benefit } & Low & 120 & 60.0 \\
\hline & High & 80 & 40.0 \\
\hline \multirow[t]{2}{*}{ Cues to Action } & Low & 110 & 55.0 \\
\hline & High & 90 & 45.0 \\
\hline \multirow[t]{2}{*}{ Self Efficacy } & Low & 111 & 55.5 \\
\hline & High & 89 & 44.5 \\
\hline \multirow{2}{*}{ Knowledge } & Low & 120 & 60.0 \\
\hline & Good & 80 & 40.0 \\
\hline \multirow{2}{*}{ Attitude } & Low & 134 & 67.0 \\
\hline & Good & 66 & 33.0 \\
\hline \multirow{2}{*}{ Access to Health Services } & Difficult & 110 & 55.0 \\
\hline & Easy & 90 & 45.0 \\
\hline \multirow{2}{*}{ Husband Support } & Weak & 123 & 61.5 \\
\hline & Strong & 77 & 38.5 \\
\hline \multirow{2}{*}{ The Use of VIA } & Have not use & 150 & 75.0 \\
\hline & Have use & 50 & 25.0 \\
\hline
\end{tabular}

\section{Bivariate Analysis}

Bivariate analysis explained the effect of one independent variables on one depen-
Univariate analysis was used to see frequency distribution and percentage characteristics of study subjects. Bivariate analysis with chi-square test and multivariate analysis with path analysis.

\section{Research Ethics}

Research ethics include information consent, anonymity, confidentiality, justice, benefit and ethical clearness in this study from the Medical Faculty of Unuversitas Sebelas Maret, Surakarta, No. 12/KEPK/2019.

\section{RESULTS}

\section{The Distribution of Study Subject}

The results of the distribution of study subjects were obtained by using VIA screening as in table 1. 
Table 2. Bivariate Analysis Determinants of VIA Utilization: Application of the Health Belief Model Theory

\begin{tabular}{|c|c|c|c|c|c|c|c|c|}
\hline \multirow{3}{*}{ Variable } & \multicolumn{4}{|c|}{ The Use of VIA Screening } & \multirow{2}{*}{\multicolumn{2}{|c|}{ Total }} & \multirow{3}{*}{ OR } & \multirow{3}{*}{$\mathbf{p}$} \\
\hline & \multicolumn{2}{|c|}{ Conduct VIA } & \multicolumn{2}{|c|}{ Not conduct VIA } & & & & \\
\hline & $\mathbf{n}$ & $\%$ & $\mathbf{n}$ & $\%$ & $\mathbf{N}$ & $\%$ & & \\
\hline \multicolumn{9}{|l|}{ Perceived } \\
\hline \multicolumn{9}{|l|}{ Susceptibility } \\
\hline Low & 117 & 58.5 & 19 & 9.5 & 136 & 68 & 5.78 & $<0.001$ \\
\hline High & 33 & 16.5 & 31 & $15 \cdot 5$ & 64 & 32 & & \\
\hline \multirow{2}{*}{\multicolumn{9}{|c|}{$\begin{array}{l}\text { Perceived } \\
\text { Severity }\end{array}$}} \\
\hline & & & & & & & & \\
\hline Low & 102 & 51 & 9 & 4.5 & 111 & $55 \cdot 5$ & 9.69 & $<0.001$ \\
\hline High & 48 & 24 & 41 & 20.5 & 89 & 44.5 & & \\
\hline \multicolumn{9}{|l|}{ Perceived } \\
\hline \multicolumn{9}{|l|}{ Benefit } \\
\hline Low & 109 & 54.5 & 11 & 5.5 & 120 & 60 & 9.43 & $<0.001$ \\
\hline High & 41 & 20.5 & 39 & 19.5 & 80 & 40 & & \\
\hline \multicolumn{9}{|c|}{ Cues to Action } \\
\hline Low & 101 & 50.5 & 9 & 4.5 & 110 & 55 & 9.39 & $<0.001$ \\
\hline High & 49 & 24.5 & 41 & 20.5 & 90 & 45 & & \\
\hline \multicolumn{9}{|l|}{ Self Efficacy } \\
\hline Low & 99 & 49.5 & 12 & 6 & 111 & $55 \cdot 5$ & 6.15 & $<0.001$ \\
\hline High & 51 & $25 \cdot 5$ & 38 & 19 & 89 & 44.5 & & \\
\hline \multicolumn{9}{|l|}{ Knowledge } \\
\hline Low & 109 & 54.5 & 11 & 5.5 & 120 & 60 & 9.43 & $<0.001$ \\
\hline Good & 41 & 20.5 & 39 & 19.5 & 80 & 40 & & \\
\hline \multicolumn{9}{|l|}{ Attitude } \\
\hline Low & 116 & 58 & 18 & 9 & 134 & 67 & 6.06 & $<0.001$ \\
\hline \multicolumn{9}{|c|}{ Access to Health } \\
\hline \multicolumn{9}{|l|}{ Services } \\
\hline Difficult & 99 & 49.5 & 11 & 5.5 & 110 & 55 & 6.88 & $<0.001$ \\
\hline Easy & 51 & $25 \cdot 5$ & 39 & 19.5 & 90 & 45 & & \\
\hline \multicolumn{9}{|l|}{ Husband } \\
\hline Support & & & & & & & & \\
\hline Weak & 104 & 52 & 19 & 9.5 & 123 & 61.5 & 3.69 & $<0.001$ \\
\hline Strong & 46 & 23 & 31 & 15.5 & 77 & 38.5 & & \\
\hline
\end{tabular}

\section{Path Analysis}

The path analysis model observed the effect of 10 variables, namely 7 endogenous variables and 3 exogenous variables. Degree of freedom (df) which showed the path analysis can be done, with df value $=35$. Model specifications would be described the influence between the variables to be studied.
Figure 1 showed that the use of VIA directly influenced by self-efficacy, cues to action, attitudes, husband's support, perceived vulnerability, perceived severity, and perceived benefits. The use of VIA was indirectly influenced through knowledge and health service access. 
Journal of Health Promotion and Behavior (2019), 4(1): 32-42

https://doi.org/10.26911/thejhpb.2019.04.01.04

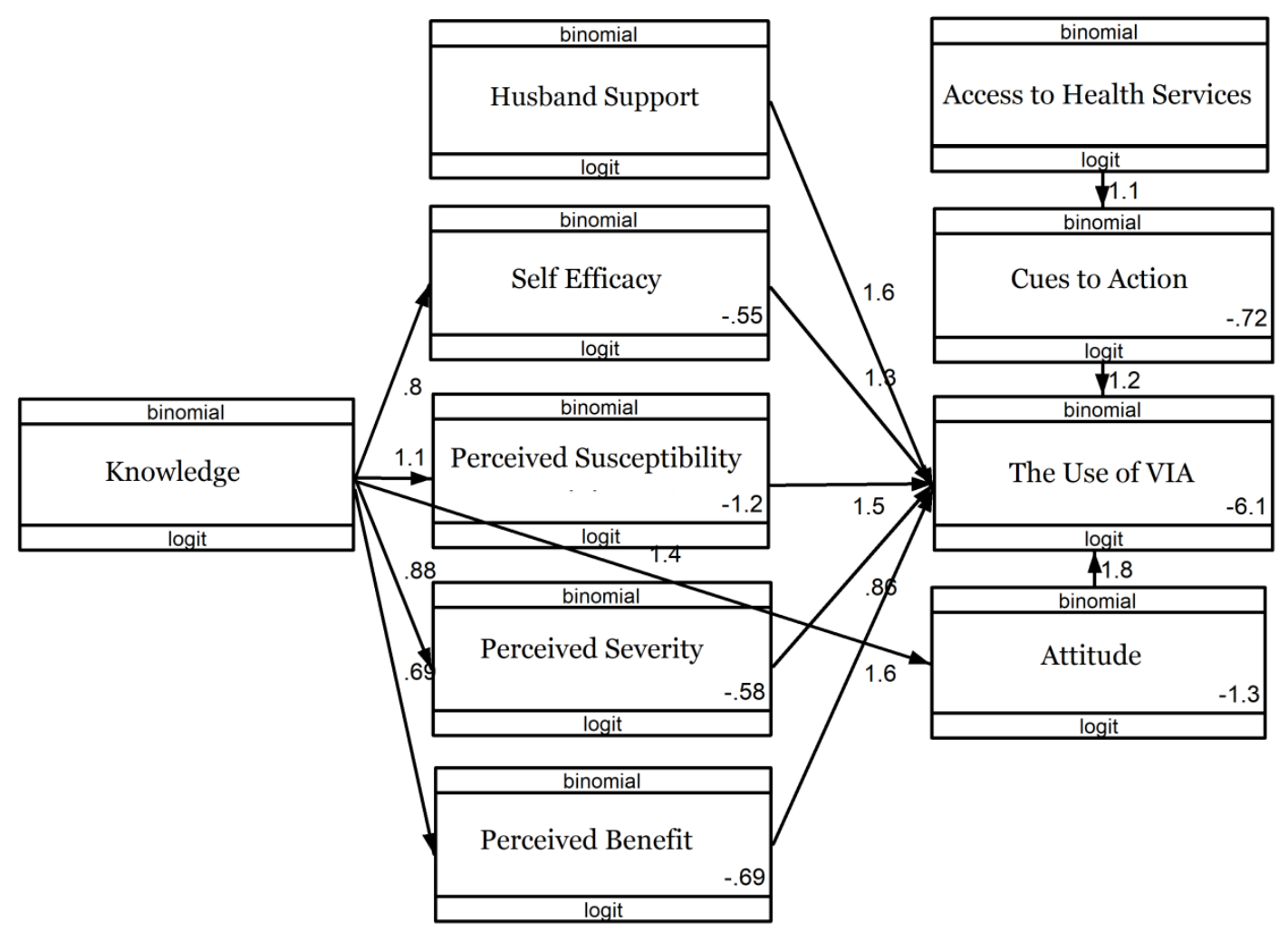

Figure 1. Structural Path Analysis Model with Estimation

Table 3. Results of determinant path analysis of the use of VIA: Application of the theory of Health Belief Model

\begin{tabular}{|c|c|c|c|c|c|c|}
\hline \multirow{2}{*}{$\begin{array}{c}\text { Dependent } \\
\text { Variable }\end{array}$} & & \multirow[b]{2}{*}{ Independent Variable } & \multirow[b]{2}{*}{ b } & \multicolumn{2}{|c|}{ CI 95\% } & \multirow[b]{2}{*}{$\mathbf{p}$} \\
\hline & & & & $\begin{array}{l}\text { Lower } \\
\text { Limit }\end{array}$ & $\begin{array}{l}\text { Upper } \\
\text { Limit }\end{array}$ & \\
\hline \multirow{8}{*}{$\begin{array}{l}\text { Direct Effect } \\
\text { The Use of VIA } \\
\text { Screening }\end{array}$} & & & & & & \\
\hline & $\leftarrow$ & Self efficacy (High) & 1.26 & 0.27 & 2.26 & 0.012 \\
\hline & $\leftarrow$ & Attitude (Good) & 1.83 & 0.81 & 2.85 & $<0.001$ \\
\hline & $\leftarrow$ & Cues to action (High) & 1.21 & 0.05 & 2.37 & 0.040 \\
\hline & $\leftarrow$ & Husband Support (Strong) & 1.59 & 0.63 & 2.55 & $<0.001$ \\
\hline & $\leftarrow$ & $\begin{array}{l}\text { Perceived Susceptibility } \\
\text { (High) }\end{array}$ & 1.45 & 0.50 & 2.40 & 0.003 \\
\hline & $\leftarrow$ & Perceived Severity (High) & 0.86 & -0.16 & 1.88 & 0.099 \\
\hline & $\leftarrow$ & Perceived Benefit (High) & 1.61 & 0.52 & 2.68 & 0.003 \\
\hline \multicolumn{7}{|l|}{ Indirect Effect } \\
\hline Cues to action (High) & $\leftarrow$ & Service Access (Easy) & 1.13 & 0.54 & 1.70 & $<0.001$ \\
\hline Self efficacy (High) & $\leftarrow$ & Knowledge (Good) & 0.80 & 0.22 & 1.37 & 0.007 \\
\hline $\begin{array}{l}\text { Perceived } \\
\text { Susceptibility (High) }\end{array}$ & $\leftarrow$ & Knowledge (Good) & 1.09 & 0.47 & 1.70 & $<0.001$ \\
\hline $\begin{array}{l}\text { Perceived Severity } \\
\text { (High) }\end{array}$ & $\leftarrow$ & Knowledge (Good) & 0.88 & 0.30 & 1.46 & 0.003 \\
\hline $\begin{array}{l}\text { Perceived Benefit } \\
\text { (High) }\end{array}$ & $\leftarrow$ & Knowledge (Good) & 0.69 & 0.11 & 1.27 & 0.019 \\
\hline \multicolumn{7}{|c|}{$\begin{array}{l}\text { N Observation }=200 \\
\text { Log likelihood }=-822.395 \\
\text { AIC }=1684.79\end{array}$} \\
\hline
\end{tabular}


Table 3 showed that self-efficacy has a direct and positive effect on the use of VIA screening. Women with high self-efficacy has a logodd to use VIA screening by 1.26 units higher $(b=1.26 ; 95 \% \mathrm{CI}=0.27$ to 2.26; $\mathrm{p}=0.012$ ) than those with low self efficacy.

There was a direct and positive influence of attitude on the use of VIA screening. Women with a good attitude has logod to use VIA screening of 1.83 units higher $(\mathrm{b}=1.83 ; 95 \% \mathrm{CI}=0.81$ to $2.85 ; \mathrm{p}=$ $<0.001)$ than those with a lack of attitude.

There was a direct and positive effect of cues to action on the use of VIA screening. Women with high cues to action had a logodd to use VIA screening by 1.21 units higher $(\mathrm{b}=1.21$; CI 95\% $=0.05$ to $2.37 ; \mathrm{p}=$ o.040) than those with low cues to action.

There was a direct and positive effect of husband support on the use of VIA screening. Women with strong husband support had a logodd to use VIA screening by 1.59 unit higher $(b=1.59$; CI $95 \%=0.63$ to 2.55 ; $\mathrm{p}<0.001)$ than those who got lack of husband support.There was a direct and positive effect of perceived susceptibility on the use of VIA screening. Women with high perceived susceptibility had a logodd to use VIA screening by1.45 unit higher $(b=1.45$; CI $95 \%=0.50$ to $2.40 ; \mathrm{p}=0.003$ ) than those with low perceived susceptibility.

There was a direct and positive effect of perceived severity on the use of VIA screening. Women with high perceived severity had a logodd to use VIA screening by 0.86 unit higher $(b=0.86$; CI 95\% $=-0.16$ to 1.88 ; $p=0.099$ ) than those with low perceived severity.

There was a direct and positive effect of perceived benefit on the use of VIA screening. Women with high perceived benefit had a logodd to use VIA screening by 1.61 unit higher $(b=1.61$; CI $95 \%=0.52$ to 2.68 ; $\mathrm{p}=0.003$ ) than those with low perceived benefit.

Service access indirectly associated to the use of VIA screening through cues to action. Women with easy service access has logodd for high cues to action by 1.13 units higher $(b=1.13 ; 95 \% \mathrm{CI}=0.54$ to 1.70 ; $\mathrm{p}<0.001)$ than those with difficult service access.

Knowledge was indirectly associated to the use of VIA screening through selfefficacy. Women with good knowledge has a logodd for high self-efficacy by 0.80 units higher $(\mathrm{b}=0.80 ; 95 \% \mathrm{CI}=0.22$ to $1.37 ; \mathrm{p}=$ 0.007 ) than those with lack of knowledge.

Knowledge was indirectly associated to the use of VIA screening through perceived vulnerability. Women with good knowledge has logodd for high perceived vulnerability by 1.09 units higher $(b=1.09$; $95 \% \mathrm{CI}=0.47$ to $1.70 ; \mathrm{p}<0.001)$ than those with lack of knowledge.

Knowledge was indirectly associated to the use of VIA screening through perceived severity. Women with good knowledge has logodd for high perceived severity by 0.88 unit higher $(b=0.88$; CI $95 \%=0.30$ to $1.46 ; p=0.003$ ) than those with lack of knowledge.

Knowledge was indirectly associated to the use of VIA screening through perceived benefit. Women with good knowledge has logodd for high perceived benefit by 0.69 unit higher $(b=0.69$; CI $95 \%=0.11$ to $1.27 ; \mathrm{p}=0.019$ ) than those with poor knowledge.

Knowledge was indirectly associated to the use of VIA screening through attitude. Women with good knowledge has logodd for good attitude by 1.38 unit higher $(b=1.38$; CI $95 \%=0.76$ to $2.01 ; p<0.001)$ than those with lack of attitude. 
Journal of Health Promotion and Behavior (2019), 4(1): 32-42

https://doi.org/10.26911/thejhpb.2019.04.01.04

\section{DISCUSSION \\ 1. The effect of perceived susceptibi- lity on the use of VIA}

The results of this study indicated that there was a direct and positive effect of perceived vulnerability on the use of VIA screening and it was statistically significant. Low perceptions were due to women's lack of knowledge of cervical cancer and the importance of VIA screening. So they did not feel that they were vulnerable to cervical cancer and did not carry out VIA test.

The results of this study were in line with the study conducted by Wakhidah et al (2017) which proved that there was an influence between perceived vulnerability and the use of VIA screening. The study showed the score of $b=0.23$ which mean that women who has a high perceived vulnerability, it would increase the use of VIA screening by 0.23 times greater than women who has a low perception.

Incidents that underlie a person's beliefs about health problems were extended because of symptoms or conditions that were diagnosed (Gochman, 1988). Likewise with women of reproductive age who realized that they were vulnerable or at risk of developing cervical cancer and would make an effort to prevent the disease by conducting VIA test.

This was in accordance with the theory of Health Belief Model developed by Rosenstock (1994) which stated that the assumption that someone was exposed to an illness would make themselves aware of a prevention and protection (Murti, 2018).

\section{The effect of perceived severity on the use of VIA}

The results of this study indicated that there was a direct and positive effect of perceived severity on the use of VIA screening and it was statistically insignificant.

The results of this study were in line with the study conducted by Wakhidah et al
(2017) which showed that there was a positive influence between perceived severity and the use of VIA screening. The study showed that women who has a high perceived severity, it would increase the use of VIA screening by 0.11 units higher than with women who have a low perceived severity. Someone would be encouraged to seek treatment and prevention of an illness if they have perceived severity about an illness(Setiyaningsih et al., 2016).

In this study the insignificance of the perceived severity on VIA screening was because women understood that cancer was a dangerous disease. However, they did not understand if women who have been active in sexual activity were at risk of cervical cancer and about the importance of VIA screening. Perception at women about the severity of cervical cancer came from how the symptoms of the pain were felt. Therefore, women did not take an action because they did not feel any symptoms so they thought they would not get cervical cancer.

\section{The effect of perceived benefit on the use of VIA}

The results of this study indicated that there was a direct and positive influence of perceived benefits on the use of VIA screening and it was statistically significant.

The more someone felt the benefits of doing an action to avoid an illness, the greater the tendency of the individual to take the action (Oktaviana et al., 2015).

The results of this study were in line with the study conducted by Wakhidah et al. (2017) which showed that there was a positive influence between perceived benefits and the use of VIA screening. The study showed that women who have high perceived benefit would increase the use of VIA screening compared to women who have low perceived benefit. A person who felt that an action might have value or benefits in reducing risk from a disease 
would tend to do the action which in this case was behavior of using VIA screening. The higher the motivation, the more positive the benefits. Knowledge support was also important in relation to perceived benefits.

\section{The effect of cues to action on the use of VIA}

The results of this study indicated that there was a direct and positive influence of cues to action on the use of VIA screening and it was statistically significant.

The results of this study were also in line with the study conducted by Pratiwi et al (2018) which showed that there was a positive effect of cues to action on the use of VIA screening. Study showed that women who have high cues to action would increase the use of VIA screening by 2.46 times higher compared to women who have a low perceived benefits.

Cues to action was needed to encourage individual involvement in health behaviors. Cues to act can come from internal factors and external factors. Internal factors include physiological signs of symptoms or health complaints. External factors such as information from family friends, health personnels, the media, etc. (Setiyaningsih et al., 2016).

\section{The effect of self efficacy on the use of VIA}

The results of this study showed that there was a direct and positive effect of self-efficacy on the use of VIA screening and it was statistically significant.

The results of this study were in line with the study conducted by Wakhidah et al (2017) which proved that there was a direct and positive influence of self-efficacy on the use of VIA screening. The study found that women who had high perceived benefit would increase the use of VIA screening compared to women who had a low perceived benefit.
Generally, someone did not try to do something new unless they can do it. If someone believed a new behavior was useful (perceived benefits), but thought that he/she was not able to do it (a perceived obstacle), it was likely that he/she would not do a behavior. The variation of this model was perceived value and determined intervention as the main beliefs. The construction of mediation factors then became a link between various types of perceptions with health behavior in the community (Murti, 2018).

Trust in someone's own abilities was the key to influence changes in health behavior. Someone's self-efficacy can be used in predicting healthy behavior and can facilitate behavior change efforts (Onoruoiza et al., 2015).

\section{The effect of knowledge on the use of VIA}

The results of this study indicated that there was an indirect and positive influence between knowledge on the use of VIA screening through perceived severity, perceived vulnerability, perceived benefit, selfefficacy, and attitudes and it was statistically significant. This result was in line with Fauza et al. (2019) who stated that Lowknowledge respondents would find it difficult to conduct VIA test.

The results of this study were also in line with the study conducted by Kurniawati et al (2015) which showed that there was a significant influence between knowledge and the use of VIA screening. The study showed that women who have high knowledge would increase the use of VIA screening by 4.30 times higher compared to women who have lack of knowledge.

Knowledge was the most important aspect of someone in shaping attitudes and behavior. Knowledge would make it easier to accept new behaviors or behavioral changes based on good knowledge, awareness 
Journal of Health Promotion and Behavior (2019), 4(1): 32-42

https://doi.org/10.26911/thejhpb.2019.04.01.04

and positive attitudes (Fitriani et al., 2018).

\section{The effect of attitude on the use of VIA}

The results of this study indicated that there was a direct and positive effect of the attitude on the use of VIA screening and it was statistically significant. Women was not enough to have good knowledge of cervical cancer and VIA screening, but it must also be reflected in attitude. Women who has a good attitude would influence the intention or desire to carry out early detection of cervical cancer through VIA screening.

The results of this study were in line with the study conducted by Saragih (2018) which showed that there was a significant effect of attitudes on the use of VIA screening. These results indicated that if women has a good attitude, it would increase the use of VIA screening by 9.16 times greater than women who have a lack of attitude.

Based on study by Ogilvie et al. (2015), it stated that attitudes can influence someone's intention to carry out an early detection of cervical cancer. The accuracy of examinations, safety, ability to protect health, and acceptance of screening affect positive judgment and a positive attitude towards early detection of cervical cancer. Attitudes can also influence a person's reason for making a decision. Attitudes would provide a basis for someone to behave in a certain way (Wardhani et al., 2017).

\section{The effect of service access on the use of VIA}

The results of this study indicated that there was an indirect and positive effect of service access through cues to action on the use of VIA screening and it was statistically significant.

The results of this study were in line with Sihombing and Windiyaningsih (2016) who stated that there was a positive influ- ence of access to services and the use of VIA screening. The study showed that women who have easy service access were 3.67 times more likely to increase the use of VIA screening compared to women who has difficult service access.

The range of affordable services for women would increase the early detection of cervical cancer, because the distance limited the ability and willingness of women to seek service. especially if transportation was limited, difficult communication, and there was no service in the area (Wardhani et al., 2017).

This study was in accordance with the study conducted by Mursyida (2012) which suggested that service quality was closely related to user satisfaction and can be a cause of behavior change in the examination of early detection of cervical cancer.

\section{The effect of husband support on the use of VIA}

The results of this study indicated that there was a direct and positive effect. The influence of husband's support through cues to act with the use of VIA screening was statistically significant.

The results of this study were in line with the study conducted by Sundari et al. (2017) which showed that there was an effect of husband's support on the use of VIA screening. These results indicated that women who have strong husband support would increase the use of VIA screening by 1.54 times higher than women who have weak husband support.

Husband support can be a driver (predisposing factor) of reproductive-age women in the use of VIA screening (Anggraeni et al., 2016). Women did not get husband's support because husbands did not understand women's health problems. As long as women did not complain about their health problems to their husbands, husbands would think that they were 
healthy (Wardhani et al., 2017). The role of the husband or family was very important for women to conduct their health check. Husband was the closest person of women in interacting and making decisions, especially in determining the place to get service (Fitriani et al., 2018).

\section{AUTHOR CONTRIBUTION \\ Elfania Arumma Sunarta formulated the study problems, designs conceptual frame- works, collected data and processed data. Endang Sutisna Sulaeman checked the results, discussion and references. Uki Ret- no Budihastuti examined data discussion and analysis.}

\section{FUNDING AND SPONSORSHIP}

This study used the authors' independent costs.

\section{ACKNOWLEDGEMENT}

The author would like to say thank you the health center, health cadres in the work area of Wongsorejo-Banyuwangi Community Health Center who assistance this study, as well as mothers who were willing to become respondents.

\section{CONFLICT OF INTEREST}

There is no conflict of interest in this study.

\section{REFERENCES}

Anggraeni FD, Murti B, Dharmawan R. (2016). Path analysis and theory of planned behavior on using papsmear as early detection of cervical cancer in Sewon I Community Health Center, Bantul, Yogyakarta, Indonesia. Journal of Health Promotion and Behavior. 1(1):1-8.https://doi.org/10.26911/thejhpb.2016.01.01.01.

Dinas Kesehatan Kota Banyuwangi.(2016). Profil kesehatan Kabupaten Banyu- wangi Tahun 2016. Banyuwangi: Kementerian Kesehatan.

Fauza M, Aprianti, Azrimaidaliza (2019). Faktor yang berhubungan dengan deteksi dini kanker serviks metode via di Puskesmas Kota Padang. Jurnal Promosi Kesehatan Indonesia, 14 (1).

Fitriani Y, Mudigdo A, Andriani RB (2018). Health belief model on the determinants of human papilloma virus vaccination in women of reproductive age in Surakarta, Central Java. Journal of Health Promotion and Behavior, 3(1): 16-26. https://doi.org/10.26911/thejhpb.2018.03.01.02.

Gochman DS (1988). Health Behavior: emerging research perspective. New york: Plenum Press.

Kementerian Kesehatan (2017). Profil Kesehatan Indonesia: data dan informasi.

KEPMENKES RI (2010). Nomor: 7926/Menkes/SK/VII/2010. Tentang kelompok kerja pengendalian penyakit kanker leher rahim dan payudara.

Kurniawati I, Wujoso H, Suryani N (2015). Pengaruh Pengetahuan, motivasi, dan dukungan suami terhadap perilaku pemeriksaan iva pada kelompok wanita usia subur di Puskesmas Kedungrejo. Universitas Sebelas Maret. Surakarta.

Mursyida RF (2012). Kepuasan Ibu hamil dan persepsi kualitas pelayanan antenatal care di Puskesmas Tanjung Kabupaten Sampang Madura. Media Kesehatan Masyarakat Indonesia, 11(2).

Murti B (2018). Teori Promosi dan perilaku kesehatan. Surakarta: Master Program of Public Health.

Ogilvie GS, Smith LW, Niekerk DJV, Khurshed F, Krajden M, et al. (2015). Women's Intentions to receive cervical cancer screening with Primary $\mathrm{Hu}-$ man Papillomavirus Testing. HHS Pu- 
Journal of Health Promotion and Behavior (2019), 4(1): 32-42

https://doi.org/10.26911/thejhpb.2019.04.01.04

blic Access. Int J Cancer, 133 (12): 2934-2943. doi:10.1002/ijc.28324.

Oktaviana MR, Nurhaeni IDA, Murti B. (2015). Hubungan antara persepsi kerentanan individu, keseriusan penyakit, manfaat dan hambatan dengan penggunaan skrining Inspeksi Visual Asam Asetat pada Wanita Usia Subur. Surakarta: Universitas Sebelas Maret

Onoruoiza SI, Musa, Umar BD, Kunle (2015). Using Health beliefs model as an intervention to non compliance with hypertension information among hypertensive patient. IOSR Journal Of Humanities and Social Science (IOSR-JHSS), 2O(9): 5 .

Pratiwi KN, Hernawati S, Rokhmah D. (2018). Determinan keikutsertaan wanita usia subur dalam pemeriksaan inspeksi visual asam asetat untuk deteksi dini kanker serviks dengan health belief model. Tesis: Digital Repository Universitas Jember.

SaragihPB (2018). Pengaruh Pengetahuan, sikap, dan persepsi terhadap pemanfaatan pelayanan deteksi dini kanker serviks metode inspeksi visual asam asetat di Puskesmas Tiga Juhar Kabupaten Deli Serdang. Jurnal Ilmiah Maksitek. 3(2).

Setiyaningsih R, Tamtomo D, Suryani N. (2016). Health Belief Model: determinants of hypertension prevention behavior in adults at Community Health Center, Sukoharjo, Central Java. Journal of Health Promotion and Behavior, 1(3): 161-171. https://doi.org/10.26911/thejhpb.2016.01.03.03.

Sihombing M, Windiyaningsih C. (2016). Faktor penentu pemeriksaan IVA pada wanita usia subur Di Puskesmas Pademangan, Suku Dinas Kesehatan Jakarta Utara 2015. Journal Bidang Ilmu Kesehatan, 7(1).

Sundari,Murti B, Suryani N (2017). Analisis jalur determinan yang mempengaruhi pemeriksaan inspeksi visual asam asetat. Seminar Nasional Kebidanan. 1(1). http://e-prosiding.unw.ac.id/index.php/snk/article/view/37.

Wakhidah MS, Hastuti URB, Dewi YLR (2017). The Influence of personal factor, husband's support, health workers and peers toward the use of IVA Screening among women of reproductive age in the regency of Karanganyar. Journal of Health Promotion and Behavior. 2(2): 124-137. https://doi.org/10.26911/thejhpb.2017.02.02. 03

Wardhani GK, Mudigdo A, Qadrijati I (2017). Path Analysis on the determinants of pap smear utilization for cervical cancer early detection in women of reproductive age. Jurnal Promosi dan Perilaku Kesehatan. 2(4): 359-370. https://doi.org/10.26911/thejhpb.2017.02.04.08.

WHO (2013). Buletin Of The World Organization.2012;90:478-478A.doi:10.2471/blt.12.103549.

WHO (2016). Human Papillomavirus (HPV) and Cervical Cancer. Retrieved from http://www.who.int/mediacentre/factsheets/fs380/en/.

WHO (2018). Human Papillovirus and cervical cancer. Retrieved from https://www.who.int/en/news-room/factsheets/detail/human-papillomavirus(hpv)-and-cervical-cancer. 